\title{
Implementation Of Restorative Justice Approach In Legal Protection Against Lightweight Crime By The Children
}

\author{
Rizky Adiyanzah Wicaksono ${ }^{1}$ and Sri Kusriyah ${ }^{2}$
}

\begin{abstract}
Children who were doing mischief that led to the crime, should be against the law to account for his actions. Currently, prevention and control delinquency that resulted in minor criminal offenses is done through the implementation of the juvenile justice system to a restorative justice approach. The concept of restorative justice becomes a very important consideration in resolving criminal cases committed by children. The Supreme Court has issued a Supreme Court Regulation (Perma) No. 2 of 2012 on the Limitation Adjustment light crime and the amount of penalties in the Criminal Code, which essentially stipulates that the value limit losses in tipiring (Lightweight Crime) case is a maximum of 2.5 million, and against the threat case maximum criminal penalty of three months imprisonment or fine, as well as in the settlement tipiring must promote Restorative Justice. Child settlement, which is directed to resolving informally or out of court, with the involvement of all parties involved in the criminal act has occurred. Minor criminal offenses committed by children under the Act No. 11 of 2012 carried through the diversion mechanism by way of mediation or deliberation.

Keywords: Restorative Justice; Lightweight Crime; Children.
\end{abstract}

\section{Introduction}

Efforts to combat criminal acts carried out through the criminal justice system. The criminal justice system or criminal justice system can be briefly defined as a system in the community to tackle crime, so that it is within the limits of public tolerance.

Son of a mandate and the grace of Allah Almighty in her inherent dignity as whole human beings. Kids should get better treatment and protection, not only from the family but also society and the state. Constitution of the Republic of Indonesia in the provisions of Article 28B paragraph (2) provide protection for children by stating that; "Every child has the right to live, grow and expand and is entitled to protection from violence and discrimination".

The position of the child as the younger generation who will continue the noble ideals of the nation, the future leaders of the nation in the future and as a source of hope for the older generation, it is necessary to get the widest possible opportunity to grow and develop with a reasonable good spiritually, physically, and socially, Child protection is a business and activities of the whole society in a variety of positions and roles, who are well aware of the importance of children for the country at a later date. If they have matured physically and mental growth and social development, then it was time

\footnotetext{
${ }^{1}$ Students of Master of Law Unissula, email: rizkywicaksono18@gmail.com

${ }^{2}$ Faculty of Law UNISSULA Semarang
} 
replaces the previous generation. ${ }^{3}$

Children as the nation's next generation should be well prepared. Keeping them out of things that are easily influenced, especially things that are negative are very important, because now the impact of globalization has begun to infect the next generation of this nation. Currently, the delinquency is increasing every year, if we look closely the development of criminal acts committed during the child, both of quality and modus operandi do, sometimes actions perceived abuses of children has been troubling all parties, especially the elderly. Understanding the delinquency or juvenile delinquency put forward by scientists vary. But in essence agreed that delinquency is an act or behavior that is anti-social. ${ }^{4}$

The influence of the progress of the times marked by the development of science and technology, culture, and development make not only adults who can violate the norms, especially legal norms. In this case, someone who is still categorized kid could do the violation of legal norms, both consciously and unconsciously. These children are generally trapped in consumerism and asocial lifestyle, more and more suggestive of criminal acts, such as taking the drug, narcotics, extortion, theft, assault, rape, theft, assault, and so on. ${ }^{5}$

Children who were doing mischief that led to the crime, should be against the law to account for his actions, which is called by children in conflict or in conflict with the law (children in conflict with the law).

The concept of legal protection in law enforcement and justice in a fair trial or justice, the establishment of which is guaranteed by the Constitution of the Republic of Indonesia Of 1945 which provides protection and benefits for every citizen in the framework of the supremacy of the Constitution as the basic law of the country. Therefore, a series of principles of fair legal process and complete, good and perfect the Constitution of the Republic of Indonesia Of 1945 and the legislation does not mean much for citizens or people who, if not enforced or implemented correctly and fair, and will create a bad image for Indonesia as a democratic constitutional state (rechtstaat en democratische). ${ }^{6}$

From the above discussion, the authors formulate the problem of: How is the Implementation of Restorative Justice Approach In Legal Protection Against Lightweight Crime By The Children?

\footnotetext{
${ }^{3}$ Maidin Gultom, 2008, Perlindungan Hukum Terhadap Anak Dalam Sistem Peradilan Pidana Anak di Indonesia, Refika Aditama, Bandung, p. 33.

${ }^{4}$ Wagiati Soetodjo, 2008, Hukum Pidana Anak, Refika Aditama, Bandung, p. 9.

${ }^{5}$ Bambang Waluyo, 2008, Pidana dan Pemidanaan, Cetakan Ketiga, Sinar Grafika, Jakarta, p. 3.

${ }^{6}$ Abdul Latif, 2014, Hukum Administrasi Dalam Praktik Tindak Pidana Korupsi, Cetakan Kesatu, Edisi Pertama, Kencana Prenada Media, Jakarta, p. 162-163.
} 


\section{Discussion}

Child protection is all the work done to create conditions so that every child can exercise its rights and obligations, to the development and growth of children is reasonably good physical, mental, and social. Child protection is the embodiment of justice in a society, thus endeavored child protection in various areas of life of the state and society. According to Munir Fuady that the purpose of legal protection in addition to achieving justice aims to create legal certainty for the private man and the public at large. ${ }^{7}$

Law is a means to regulate and protect the interests of the community. Every member of society must carry out the obligations and obtain their own right so that no one will be harmed. Legal protection has meaning as protection by means of law or the protection afforded by the law, aimed at the protection of particular interests, namely by making the interests that need to be protected into a legal right. ${ }^{8}$

Those goals are sometimes subject to failure, because it tends to be repeat offenders of crime he has done (recidivists), and yet again if people could imitate commit those crimes. This is because the application of criminal sanctions can not see the root of the problem which is the cause of a crime. Therefore, it takes some thinking to do a social approach in addition to the application of criminal sanctions. ${ }^{9}$

The increasing number of crimes committed by children, thus making the law enforcement agencies should make efforts to overcome and eradicate the criminal application to children. The application of the criminal to juvenile offenders is expected to provide deterrence to other children and society in general to not do the crime. But this goal is sometimes a failure, because it tends to be repeat offenders of crime he has done (recidivists), and yet again if people could imitate commit those crimes. This is because the application of criminal sanctions can not see the root of the problem which is the cause of a crime. Therefore, it takes some thinking to do a social approach in addition to the application of criminal sanctions. ${ }^{10}$

In the development of child protection in conflict with the law develops the concept restorative justice, namely the concept of settlement of conflicts by involving the parties concerned with the crime that occurred (victims, offenders, families of the victims, families and intermediate actors (moderator). ${ }^{11}$

\footnotetext{
${ }^{7}$ Munir Fuady dan Muchtar Wahid, 2008, Memaknai Kepastian Hukum Hak Milik Atas Tanah, Suatu Analisis Dengan Pendekatan Terpadu Secara Normatif dan Sosiologis, Republika, Jakarta, p. 86.

${ }^{8}$ Harjono, 2008, Konstitusi Sebagai Rumah Bangsa, Sekretariat Jenderal dan Kepaniteraan Mahkamah Konstitusi Republik Indonesia, Jakarta, p. 373.

${ }^{9}$ Marlina, 2009, Peradilan Pidana Anak di Indonesia : Pengembangan Konsep Diversi dan Restorative Justice, Refika Aditama, Bandung, p. 17.

${ }^{10} \mathrm{Ibid}$.

${ }^{11}$ Marlina, 2010, Pengantar Konsep Diversi dan Restorative Justice Dalam Hukum Pidana, USU Press, Medan, p. 2.
} 
Child protection activities bring legal consequences, both in relation to the written law and the law does not written. The protection of children do naturally, so it does not make children become spoiled because children will feel as if the act of doing is correct, but must be treated well and not judge young people. Child protection should not be overdone and considering the impact on the environment and to the child itself, so that safeguards do not have negative consequences. Child protection will be implemented rational, responsible and rewarding reflecting an effective and efficient business. Protection efforts may not result in the demise of the initiative, creative, etc that caused depenciancy to others and act with uncontrolled, so the child has not the ability dan desire to us his right and do his responsibility. ${ }^{12}$

Case investigation of tipiring as stipulated in Article 205 paragraph (1) Criminal Procedure Code stipulates that "What is checked according to the examination of minor criminal offenses is a case that is punishable by imprisonment or confinement of a maximum of three months and / or a fine of up to seven thousand five hundred rupiah and mild contempt unless specified in paragraph 2 of this section. In the application case of theft has been committed by children or adults Rp.2,5 million with a maximum value limit losses or the amount of fines in cases tipiring, the Supreme Court has issued a Supreme Court Regulation (Perma) No. 2 of 2012 on the Limitation Adjustment light crime and Total fines in the Criminal Code, which essentially stipulates that the value limit losses in case tipiring is a maximum of 2.5 million.

Perma was issued in response to some of the provisions in the Criminal Code related to limit losses and penalties, which are considered no longer relevant to the development of current conditions. Perma is also intended to avoid the accumulation of cases at the Supreme Court as well as avoid the application of the articles of common crime in the case of less serious crimes, the perpetrators are not required to be retained and need not be filed cassation. The investigation carried out by the fast events as stipulated in Article 205-211 Criminal Procedure Code and the court settlement is possible by promoting Restorative Justice.

As a follow up, in October 2012, the Supreme Court together with the Prosecutor, the Police, and Kemenkumham have made a Memorandum of Understanding related to the implementation of the Perma No. 2 2012. This Memorandum of Understanding for restorative justice (restoration of justice), especially for juvenile criminal cases and misdemeanors with fines or loss is the value below 2.5 million.

Settling disputes through restorative justice is no longer looking for who is right and who is wrong and seek punishment of what is appropriate given to the guilty parties are, as desired by restorative justice is a restoration of the offender so that he will no longer commit crimes, the recovery of the victim as the aggrieved party as well as the

\footnotetext{
${ }^{12}$ Ibid., p. 34.
} 
relationship between the victim, the offender, and the community to his way of life can return to normal.

Restorative justice placing a higher value on the direct involvement of the parties. Victims were able to restore a sense of confidence and eliminate the fear, while offenders are encouraged to take responsibility as a step in correcting errors caused by the crime and in building social value system. Children who become perpetrators of minor criminal offenses should take precedence interests, either during the proceedings that took place and the time children undergo criminal. Restorative justice approach is child problem-solving approach is most appropriate for the crime of child solve the problem because the approach is viewed from the welfare and protection of children.

Susan Sharpe suggests there are five principles of restorative justice, namely: ${ }^{13}$

- Restorative justice containing the full participation and consensus. In this case the victim and the offender should be actively involved in the negotiations to find a comprehensive settlement. In addition, open up opportunities for people who have been bothered security and order by the offender to break sat with this issue;

- Restorative justice looking for solutions to restore and heal the damage or loss as a result of criminal offenses committed by the offender. This includes the effort to cure or recovery of victims for acts the crime that happened;

- Restorative justice provides a complete sense of responsibility for the perpetrators to be responsible for his actions. Perpetrators must show a sense of completion and admit all the mistakes and realize that his actions cause harm to others;

- Restorative justice trying to reunite actors as citizens with people who have been separated as a result of a criminal act. This is done by holding reconciliation between victims and offenders and reintegrate back both in public life normally. Both of them should be freed from his past for the sake of a brighter future;

- Restorative justice give strength to the community to prevent the crime from happening again. Crime wreaking havoc in people's lives, but evil can be a learning experience for people to open real justice for all people. This is because the correlative factor criminogen more likely stems from the existing problems within the community, such as economic factors, social, cultural, and not sourced from inside offender. Therefore, the victim and the offender must re-placed to maintain the integrity of society and positioned according to its function in society.

Restorative justice or justice within their restorative justice theory proposed by John Rawls, which basically state it comes from the community itself, so to solving problems must be communities themselves working on it. John Rawls confirming it with the idea

${ }^{13}$ Marlina, 2011, Hukum Penitensier, Refika Aditama, Bandung, p. 74-75. 
of justice as fairness, a theory of justice which generalizes and raised the traditional conception of the social contract to a higher level of abstraction. ${ }^{14}$

According to John Rawls, the primary subject of justice is the basic structure of society, or more precisely, the way major social institutions distribute fundamental rights and duties and determine the division of advantages from social cooperation. ${ }^{15}$, The principles of justice for the basic structure of society is the aim of the agreement, these principles will govern the agreement further, they determine what kind of social cooperation that can be entered and the forms of government that can be established, the perspective of the principle of justice is that according to John Rawls called justice as fairness. ${ }^{16}$

The concept of restorative justice becomes a very important consideration in resolving cases of minor criminal offenses committed by children. Law enforcement officials in conducting misdemeanor case investigation done by children should consider the implementation of the partial diversion agreement, and provide an opportunity for parents, guardians, foster parents to raise any matters of that benefit children. Against children, can be punished or action in the form:

- Returns to parents, guardians and foster parents;

- Handed over to the state for education, training and vocational training; or

- Submit to the Department of Social Services, or Social Community Organizations working in the field of education, training and job training.

The principles of justice been in a state without the knowledge, this ensures that no one benefited or harmed in the selection principles with the result of natural chance or the contingency situations sosia1. ${ }^{17}$ Justice as fairness, expressing the idea that the principles of justice agreed in the ideal situation fairer. ${ }^{18}$ Justice as fairness, like other contract view, consists of two parts, namely the interpretation of the initial situation and on the issue of options, and a set of principles to be agreed. ${ }^{19}$ And is reasonable and acceptable if there may be gainers and losers by natural destiny or social situations in the selection principle. ${ }^{20}$

The theory of justice as fainess by John Rawls, which is also referred to as a theory of contract, ${ }^{21}$ where the community as a major subject of justice has an agreement in choosing a principle, in which no party beneficially or adversely affected. John Rawls's theory of justice in line with the concept of restorative justice, where the main purpose

\footnotetext{
${ }^{14}$ John Rawls, 2011, A Theory of Justice, terjemahan Teori Keadilan, Pustaka Pelajar, Yogyakarta, p. 3.

${ }^{15}$ Ibid., p. 7-8.

${ }^{16}$ Ibid., p. 12-13.

17 Ibid,

${ }^{18}$ Ibid., p. 14.

${ }^{19}$ Ibid., p. 17.

${ }^{20}$ Ibid., p. 21.

${ }^{21}$ Ibid., p. 18.
} 
of justice is to restore relationships between offenders, victims and the community as a result of a criminal act with the agreement taken by the offender, the victim and the community. No gainers and losers in principle be sought remedies are equally beneficial parties (win-win solution).

In making decisions regarding the child's future, rather than by using the size of an adult, let alone an adult-centered interests. What do you think adults both, not necessarily the better the interests of the child according to size. Perhaps the intent of adults to provide assistance and help, but verily came the destruction of the child's future. $^{22}$

Restorative justice approach is a form of legal reforms that not only change the law but also to modify the criminal justice system. As is well known that one of the mechanisms of restorative justice is to settle matters through deliberation and consensus, known as diversion mechanism.

\section{Closing}

\subsection{Conclusion}

Legal protection of children in the implementation of the theft has been committed by children or adults with a maximum limit losses Rp.2,5 million. The law enforcement officials should prioritize methods of Restorative Justice which is a recovery of the child so that he will no longer commit crimes, the recovery of the victim as the injured party as well as the relationship between the victim, the offender, and the community to his way of life can return to normal.

\subsection{Suggestion}

It needs a socialization of the restorative justice approach to law enforcement and the community, as well as facilities and infrastructure to carry out the diversion mechanism must be fulfilled for the salvation of the future of children who have committed minor criminal offenses.

\section{Bibliography}

[1] Abdul Latif, 2014, Hukum Administrasi Dalam Praktik Tindak Pidana Korupsi, Cetakan Kesatu, Edisi Pertama, Kencana Prenada Media, Jakarta.

[2] Bambang Waluyo, 2008, Pidana dan Pemidanaan, Cetakan Ketiga, Sinar Grafika, Jakarta.

\footnotetext{
${ }^{22}$ Hadi Supeno, 2010, Kriminalisasi Anak: Tawaran Gagasan Radikal Peradilan Anak Tanpa Pemidanaan, Gramedia Pustaka Utama, Jakarta, p. 56.
} 
[3] Hadi Supeno, 2010, Kriminalisasi Anak: Tawaran Gagasan Radikal Peradilan Anak Tanpa Pemidanaan, Gramedia Pustaka Utama, Jakarta.

[4] Harjono, 2008, Konstitusi Sebagai Rumah Bangsa, Sekretariat Jenderal dan Kepaniteraan Mahkamah Konstitusi Republik Indonesia, Jakarta.

[5] John Rawls, 2011, A Theory of Justice, terjemahan Teori Keadilan, Pustaka Pelajar, Yogyakarta.

[6] Maidin Gultom, 2008, Perlindungan Hukum Terhadap Anak Dalam Sistem Peradilan Pidana Anak di Indonesia, Refika Aditama, Bandung.

[7] Marlina, 2009, Peradilan Pidana Anak di Indonesia : Pengembangan Konsep Diversi dan Restorative Justice, Refika Aditama, Bandung.

[8] Marlina, 2010, Pengantar Konsep Diversi dan Restorative Justice Dalam Hukum Pidana, USU Press, Medan.

[9] Marlina, 2011, Hukum Penitensier, Refika Aditama, Bandung.

[10] Munir Fuady dan Muchtar Wahid, 2008, Memaknai Kepastian Hukum Hak Milik Atas Tanah, Suatu Analisis Dengan Pendekatan Terpadu Secara Normatif dan Sosiologis, Republika, Jakarta.

[11] Wagiati Soetodjo, 2008, Hukum Pidana Anak, Refika Aditama, Bandung. 